MUDRA: Journal of Finance and Accounting, Volume 4, Issue 2, July-December 2017, pp. 112-126

doi: 10.17492/mudra.v4i02.11865

\title{
FDI Performance and Policy of India and China: A Comparative Analysis
}

\author{
Rahul Bhasin* and KV Bhanu Murthy**
}

\begin{abstract}
The competition among countries to attract foreign direct investment (FDI) has increased significantly in the last two decades. While comparing FDI flows across countries, the comparison between India and China is a significant area of interest as these two countries enjoy strong similarities with each other in terms of population and market size and are also among the top prospective host economies for FDI inflows. However, they differ significantly in terms of their FDI performance. While China remains the largest host country in the developing world in terms of FDI inflows, India has been unable to attract comparable FDI inflows despite having a huge market. This paper analyses the aggregated as well as segregated trends in FDI inflows of both the countries and also presents a comparative analysis of the two countries in terms of their FDI policies and other macroeconomic factors. The analysis reveals that India needs further liberalization of its FDI policy and norms along with developing competitive infrastructure and business-friendly procedures.
\end{abstract}

Keywords: Foreign direct investment (FDI); Liberalisation; Market size; Infrastructure; India; China.

\subsection{Introduction}

The last two decades have witnessed intense competition among countries, particularly developing economies, to attract foreign direct investment (FDI). This is because FDI enables them to boost their domestic rates of investment and also to acquire new technology and managerial skills. The competition among less developed and developing countries to lure foreign investors is evident in policies related to offering repatriation facilities, tax concessions and other incentives.

*Corresponding author; Ph. D. Research Scholar, Mewar University, Chittorgarh, Rajasthan, India. (Email id: rahul_b12@rediffmail.com; rahulb1509@gmail.com)

**Professor, Delhi Technological University, Delhi, India; Formerly Dean, Faculty of Commerce and Business, Delhi School of Economics, University of Delhi, Delhi, India. (Email id: bhanumurthykv@yahoo.com) 
The global trends in FDI and the attitude of the developing world towards it have shown marked changes over the last few decades. During the period 1950-1980, most developing countries of the world relied on restricting imports, promoting exports and adopting import substitution along with pegged exchange rate regime.

The growth of FDI flows to developing countries is unevenly distributed among regions and groups of developing countries. Most FDI flows continue to be concentrated in 10 to 15 host countries, overwhelmingly in Asia and Latin America. While comparing FDI flows across countries, the comparison between India and China becomes inevitable as they enjoying some similarities with each other in terms of population and market size. China has been the largest host country in the developing world for many years successively in terms of FDI inflows. India, on the other hand, has been unable to attract comparable FDI inflows despite enjoying having a huge market and rising purchasing power of people. This paper analyses the trends in FDI flows of India and China and then attempts to compare the economic policies as well as FDI regime of these two countries to identify the reasons for the difference in FDI performance.

\subsection{Trends in FDI Flows to India and China}

\subsection{FDI Trends in India}

Since its liberalisation in 1991, India has seen a consistent rise in FDI over almost 2 decades till 2008 with around 200\% increase i.e., from USD 0.3 billion from 1992 to USD 47 billion. Post 2008, a downward trend was observed on account of global recession till 2014, till the FDI in India bounced back with 44 billion USD in 2015 with increasing trend of USD 44.4 billion in 2016. (Table 1 and Figure 1) Despite the slight increase of $1 \%$ in FDI in 2016 over the previous year, India is not ranked anymore among the top 10 host economies for FDI, according to the United Nations Conference on Trade and Development (UNCTAD's) World Investment Report, 2017. However, in terms of "greenfield investments", India continued to outrank both China and the U.S. as the world's top destination for capital investment in 2016, with USD 62.8 billion-worth of FDI projects announced, according to the same report.

FDI outflow also shows the increasing trend in line the Inflow post liberalisation since 1992. Over the 2 decades till 2008, surprisingly it grows at much faster rate at around $800 \%$ from USD 0.2 billion in 1992 to the highest ever mark of USD 210 billion, beats even inflow in terms of percentage increase. Since then it also shows a decreasing trend till 2013 to reach at a low level of only USD 1.7 billion, and then bounce back to USD 11.8 billion in 2014 to carry on with decreasing tend in 2015 and 2016 with USD 7.6 and 5.1 billion respectively. 
Table 1: FDI Inflows and Outflows of India, 1990-2016

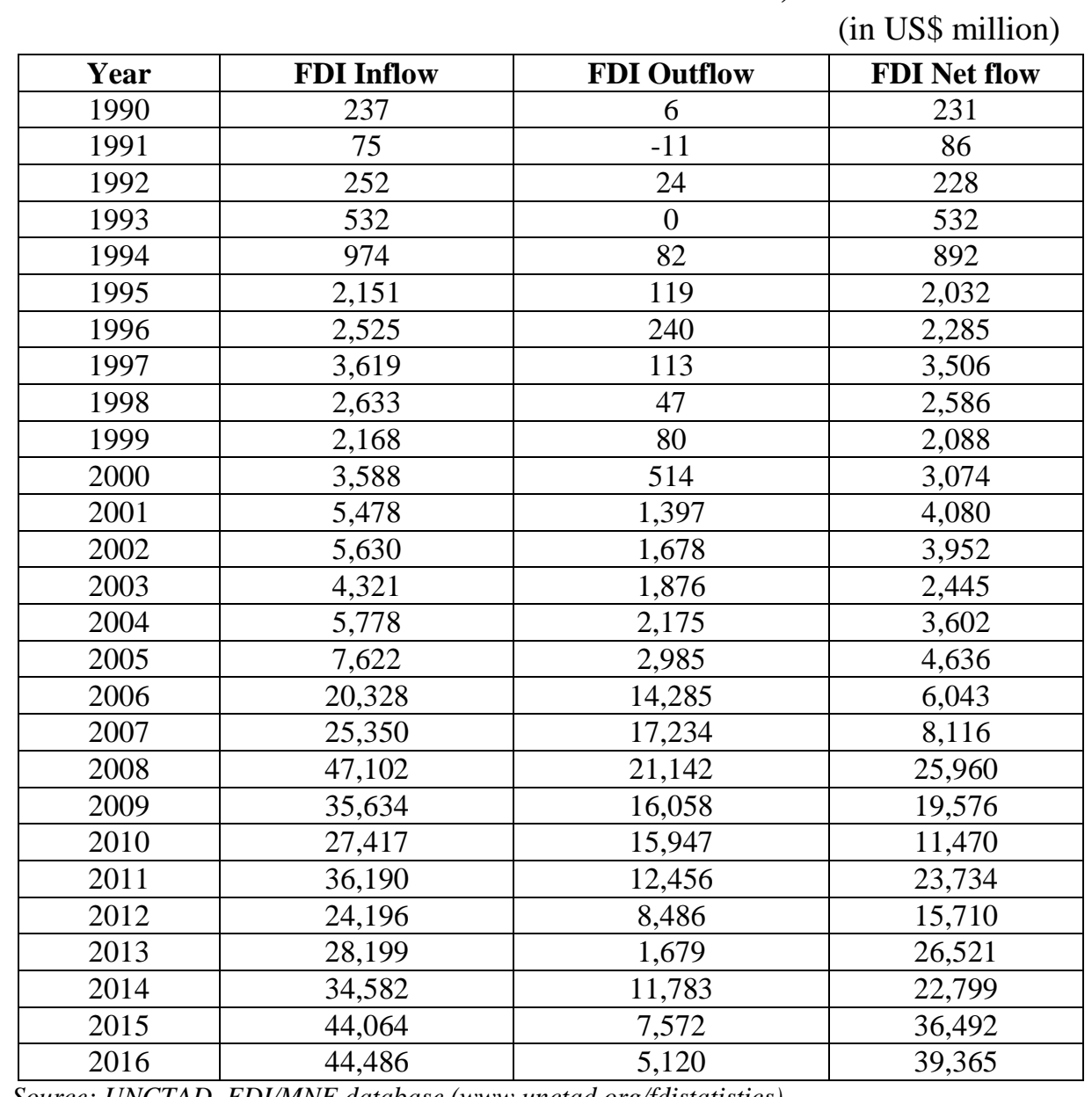

Source: UNCTAD, FDI/MNE database (www.unctad.org/fdistatistics)

The FDI growth in India is mainly on account of its various assets, especially its high degree of specialised workforce in services with a skilled, English speaking and low cost labour force, a potential market of over one billion inhabitants and 53\% of its population as working population (16-64 yrs.). Over the previous decade, the major reason for FDI downtrend was due to Eurozone debt crises, corruption scandals and political crises that eroded investor trust. To get the economy back on track and pull back the investment in India, in the past few years number of reforms have been introduced and opening of the single brand retail sector to foreign investment is one of them. In addition, various amendments have been made in old policies in favour of foreign investors, which has resulted in India going up 30 ranks within a year in 'ease of 
doing business'. It moved from $130^{\text {th }}$ position in 2016 to $100^{\text {th }}$ position in 2017 out of 190 countries (Doing Business Report published by the World Bank).

Figure 1: FDI Inflows and Outflows of India, 1990-2016

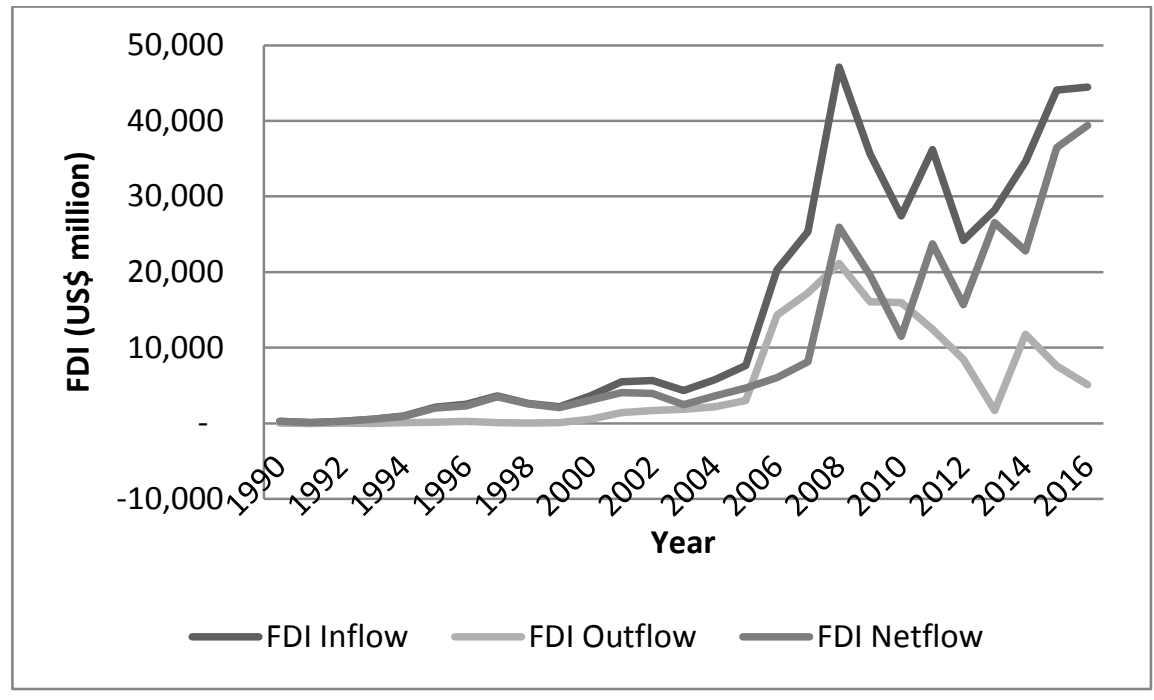

Source: UNCTAD, FDI/MNE database (www.unctad.org/fdistatistics)

\subsubsection{FDI by investing countries}

A large part of FDI flowing into India is from developing countries of the world. Table 2 shows the top investing countries in India for the year 2015 in terms of \% of total FDI flows. The greatest FDI equity inflows to India come from Mauritius, Singapore, Japan, the UK, the U.S. and the Netherlands, with the top two (Singapore and Mauritius) jointly accounting for $50 \%$ of total FDI (Table 2). The large amount of FDI from Mauritius and Singapore is attributable to the concessional provisions of the Double Taxation Avoidance Agreements (DTAAs) that India has with these countries. There are sizeable capital gains tax concessions that are provided to investors who are beneficiaries under these treaties.

\subsubsection{FDI by sectors}

In terms of sectoral distribution, the sectors which account for largest part of FDI inflows in India are services sector, construction, telecommunications, it \& software and car industry (Table 3). These four sectors jointly account for around 50\% of total FDI inflows. 
116 | MUDRA: Journal of Finance and Accounting, Volume 4, Issue 2, Jul-Dec 2017

Table 2: FDI Inflows in India by Investing Countries for the year 2015

\begin{tabular}{|l|c|}
\hline \multicolumn{1}{|c|}{ Investing country } & Share in total FDI inflows to India (\%) \\
\hline Mauritius & 34 \\
\hline Singapore & 16 \\
\hline Japan & 8 \\
\hline United Kingdom & 8 \\
\hline USA & 6 \\
\hline The Netherlands & 6 \\
\hline Germany & 3 \\
\hline Cyprus & 3 \\
\hline France & 2 \\
\hline UAE & 1 \\
\hline
\end{tabular}

Source: Department of Industrial Policy and Promotion, Ministry of Commerce and Industry, India.

Table 3: FDI Inflows in India by Sectors for the year 2015

\begin{tabular}{|l|c|}
\hline \multicolumn{1}{|c|}{ Sector } & Share in total FDI inflows to India (\%) \\
\hline Services sector & 18 \\
\hline Construction & 8 \\
\hline Telecommunications & 7 \\
\hline IT and software & 7 \\
\hline Car industry & 5 \\
\hline Drugs and pharmaceutical & 4 \\
\hline Trade & 4 \\
\hline Chemical (except fertilisers) & 4 \\
\hline Energy & 4 \\
\hline Metallurgy & 3 \\
\hline Source: Department of Industrial Policy and Promotion, Ministry of Commerce and Industry, India.
\end{tabular}

\subsection{FDI Trends in China}

According to the UNCTAD's World Investment Report, 2017, China was ranked the world's third largest FDI recipient after United States and the UK. The country's economy was ranked the second most attractive to multinational companies for 20172019, after the United States. The absorption of FDI is part of the policy of opening China to the outside world. Table 4 and Figure 2 present the trends in FDI inflows and FDI outflows of China. In 2016, FDI inflows reached USD 133 billion, not far from the historic high of USD 135 billion in 2015. FDI flows from China abroad, valued at USD 
183 billion in 2016, outpaced FDI flows into the country. China has a large and rapidly expanding market, which was not overly affected by the financial crisis. With a strong potential, a wealth of employees and potential partners eager to learn and evolve, the country is a base for low cost production. Nevertheless, certain factors can hinder investments, such as China's lack of transparency, legal uncertainty, low level of protection of intellectual property rights, corruption or protectionist measures which favour local businesses.

Table 4: FDI Inflows and Outflows of China, 1990-2016

\begin{tabular}{|c|c|c|c|}
\multicolumn{5}{|c}{} & \multicolumn{2}{c|}{ (in US\$ million) } \\
\hline Year & FDI Inflow & FDI Outflow & FDI Net flow \\
\hline 1990 & 3,487 & 830 & 2,657 \\
\hline 1991 & 4,366 & 913 & 3,453 \\
\hline 1992 & 11,008 & 4,000 & 7,008 \\
\hline 1993 & 27,515 & 4,400 & 23,115 \\
\hline 1994 & 33,767 & 2,000 & 31,767 \\
\hline 1995 & 37,521 & 2,000 & 35,521 \\
\hline 1996 & 41,726 & 2,114 & 39,612 \\
\hline 1997 & 45,257 & 2,562 & 42,695 \\
\hline 1998 & 45,463 & 2,634 & 42,829 \\
\hline 1999 & 40,319 & 1,774 & 38,544 \\
\hline 2000 & 40,715 & 916 & 39,799 \\
\hline 2001 & 46,878 & 6,885 & 39,992 \\
\hline 2002 & 52,743 & 2,518 & 50,224 \\
\hline 2003 & 53,505 & 2,855 & 50,650 \\
\hline 2004 & 60,630 & 5,498 & 55,132 \\
\hline 2005 & 72,406 & 12,261 & 60,145 \\
\hline 2006 & 72,715 & 17,634 & 55,081 \\
\hline 2007 & 83,521 & 26,506 & 57,015 \\
\hline 2008 & $1,08,312$ & 55,907 & 52,405 \\
\hline 2009 & 95,000 & 56,529 & 38,471 \\
\hline 2010 & $1,14,734$ & 68,811 & 45,923 \\
\hline 2011 & $1,23,985$ & 74,654 & 49,331 \\
\hline 2012 & $1,21,080$ & 87,804 & 33,276 \\
\hline 2013 & $1,23,911$ & $1,07,844$ & 16,067 \\
\hline 2014 & $1,28,500$ & $1,23,120$ & 5,380 \\
\hline 2015 & $1,35,610$ & $1,27,560$ & 8,050 \\
\hline 2016 & $1,33,700$ & $1,83,100$ & $-49,400$ \\
\hline
\end{tabular}

Source: UNCTAD, FDI/MNE database (www.unctad.org/fdistatistics) 
Figure 2: FDI Inflows and Outflows of China, 1990-2016

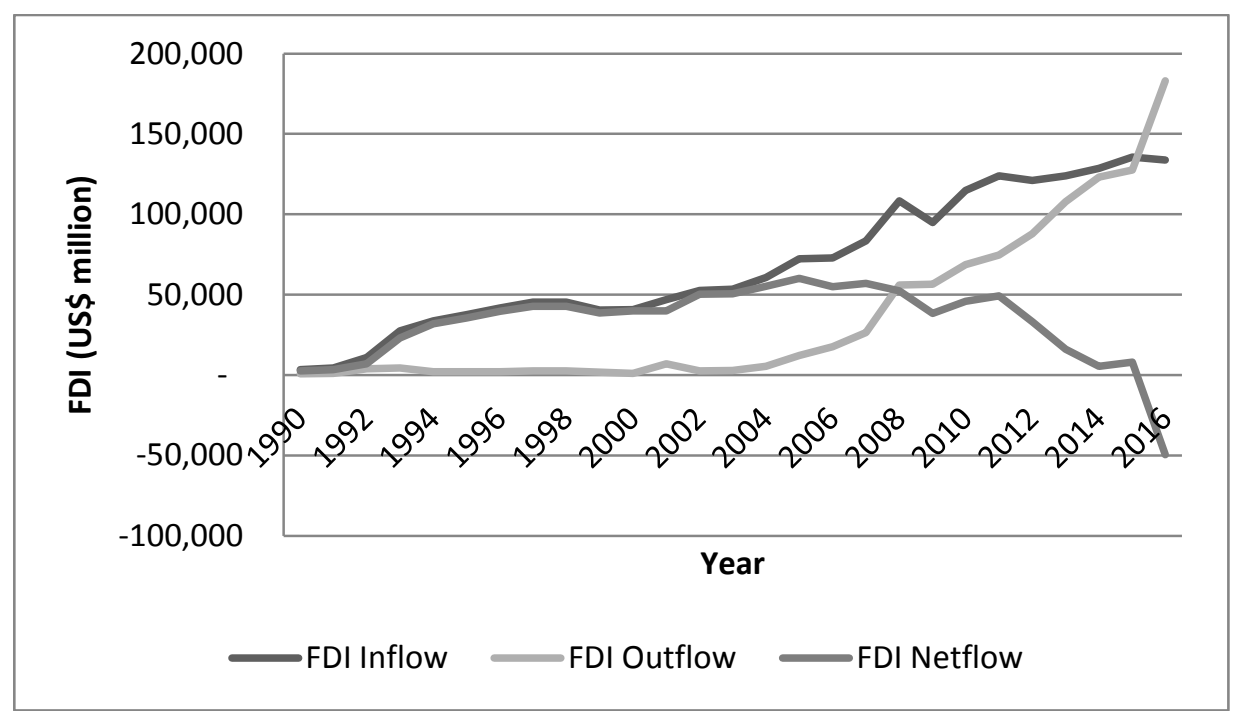

Source: UNCTAD, FDI/MNE database (www.unctad.org/fdistatistics)

\subsubsection{FDI by investing countries}

A large part of FDI flowing into China by the developing countries of the world, mainly Asia. Table 5 shows the top investing countries in China for the year 2015 in terms of $\%$ of total FDI flows. A number of countries from the Asia region are biggest contributor to FDI such as Hong Kong, Singapore and South Korea, followed by USA and other north east counties like Macao, Taiwan, Taiwan and Japan.

Table 5: FDI Inflows by in China by Investing Countries for the year 2015

\begin{tabular}{|l|c|}
\hline \multicolumn{1}{|c|}{ Investing country } & Share in total FDI inflows to China (\%) \\
\hline Hong Kong & 69 \\
\hline Singapore & 5 \\
\hline South Korea & 4 \\
\hline USA & 3 \\
\hline Macao & 3 \\
\hline Taiwan & 3 \\
\hline Japan & 3 \\
\hline Germany & 2 \\
\hline UK & 2 \\
\hline Luxembourg & 1 \\
\hline
\end{tabular}

Source: Invest in China - Latest available data. 


\subsubsection{FDI by Sectors}

In terms of sectoral distribution, the sectors which account for largest part of FDI inflows in China are Manufacturing, Real estate, Business services \& renting, Wholesale $\&$ Retail trade which account for around $76 \%$ of its total FDI. (Table 6 )

Table 6: FDI Inflows in China by Sectors for the year 2015

\begin{tabular}{|l|c|}
\hline \multicolumn{1}{|c|}{ Sector } & Share in total FDI inflows to China (\%) \\
\hline Manufacturing & 43.2 \\
\hline Real estate & 20.9 \\
\hline Business services and renting & 6.2 \\
\hline Wholesale and retail trade & 5.7 \\
\hline $\begin{array}{l}\text { Transport, storage, telecommunications, } \\
\text { postal services }\end{array}$ & 2 \\
\hline
\end{tabular}

Source: Invest in China - Latest available data.

\subsection{FDI Inflows of India versus China}

Figure 3 presents a comparison of FDI inflows of India and China over the period 2006-2016. As is evident from Figure 3, China has been consistently drawing much more FDI than India while they both rank high as prospective FDI destinations. Section 4 below examines the reasons behind this significant difference in FDI performance of the two countries.

Figure 3: FDI Inflows of India and China, 2006-2016 (US\$ billion)

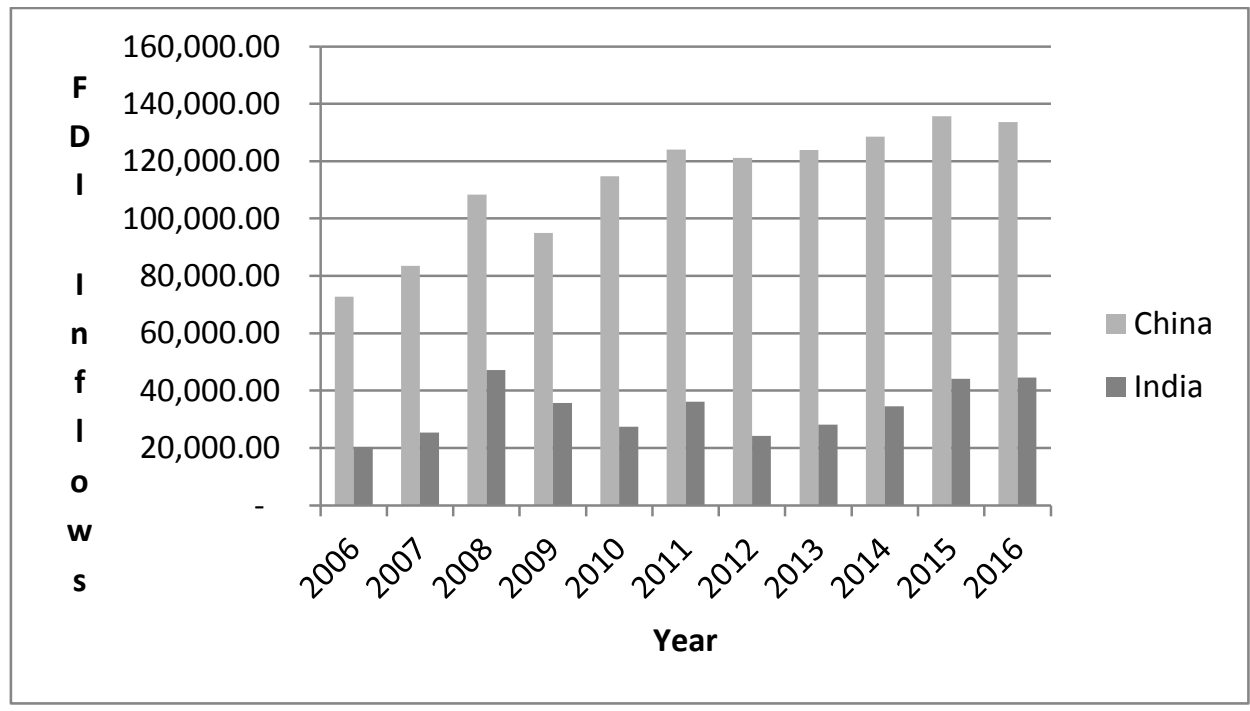

Source: UNCTAD, FDI/MNE database (www.unctad.org/fdistatistics) 
120 | MUDRA: Journal of Finance and Accounting, Volume 4, Issue 2, Jul-Dec 2017

\subsection{Literature Review}

There exists considerable literature on the factors that determine the FDI flows to a country. The existing literature includes a large number of surveys and case studies and a number of econometric studies. In general, they conclude that the main factors which drive FDI into a country have been market size (generally determined by a country's GDP and GDP per capita), openness, infrastructure quality, taxes and tariffs, labour costs and the degree of political and economic stability. However, the importance of these determinants vary across countries and regions. Further, the significance of determinants also changes over a period of time.

The factors that have conventionally emerged as important determinants of FDI are market size, purchasing power, growth prospects, labour conditions (availability and cost), FDI openness, trade openness, exchange rate, inflation, education, tax rates, and infrastructure. (Mina, 2007; Sury, 2008; Kahai, 2011; Akin and Vlad, 2011; Wernick and Haar, 2009; Goswami and Haider, 2014; Murthy and Bhasin, 2015).

Noorbakhsh et al. (2001) found a significant relationship between level of human capital and geographical distribution of FDI using panel estimation technique for developing countries. Many studies have found FDI to be significantly affected by corruption levels (Habib and Zurawicki, 2002; Cuervo-cazurra, 2006; and Godinez and Liu, 2015) have analysed the impact of corruption on FDI and found significant results. The findings also showed that investors who have faced corruption at home are likely to be unaffected or sometimes positively affected by corruption levels in host country.

Julio and Yook (2016) also studied the effect of political uncertainty (election timing) on FDI flows from US companies and found that political uncertainty deters FDI. Ali and Guo (2005) and Fung et al. (2005) studied FDI determinants in China and found a number of significant variables, like market size, low labour cost, institutional and market reforms, etc.

Fedderke and Romm (2006) found some factors to enhance the attractiveness of South Africa for FDI i.e. lower political risk, better property rights, growth in market size, reducing corporate tax rates, and complete global integration. Aw and Tang (2010) studied FDI factors for Malaysia and found corruption and China accession to the WTO to be significant factors. Dumludag (2009) found many institutional determinants of FDI in Turkey such as corruption freedom, IPR, government stability, political and economic conditions, etc. to be significantly affecting FDI. 


\subsection{FDI Regimes and Economic Policies of India and China: A Comparative Analysis}

As per UNCTAD's survey of top prospective host economies worldwide for 20172019, China and India rank $2^{\text {nd }}$ and $3^{\text {rd }}$ respectively (UNCTAD's World Investment Report, 2017, p. 9). While both the countries enjoy a high ranking among prospective investors as a preferred FDI destination, China bypasses India in large amounts in terms of actual flows of FDI. For the year 2016, while India attracted $\$ 44.5$ billion, China attracted \$133.7 billion of FDI inflows (UNCTAD's World Investment Report, 2017, $\mathrm{p}$ 49).

FDI has contributed to the rapid growth of China's merchandise exports while FDI has been much less important in driving India's export growth. FDI in Indian manufacturing still remains domestic market-seeking. For China, the major share of FDI inflows goes to a broad range of manufacturing industries. For India, most of it goes to services, electronics and electrical equipment and engineering and computer industries. The difference in their FDI performance is attributable to basic determinants, development strategies and overseas networks. The section below presents a comparative analysis of determinants and FDI policies underlying the different FDI performance of India and China.

\subsection{FDI policies and procedures}

(a) Thrust sectors: China has declared that, it will encourage investment in the following industries or sectors: high technology, production of equipment or new materials, the service sector, recycling, clean production, the use of renewable energies and environmental protection. At the same time, the Government plans to restrict foreign investment in resource-intensive and highly-polluting industries. In addition, foreign investment is discouraged in sectors which are deemed key to social stability, or in which China seeks to develop domestic firms into globally competitive multinational corporations, or sectors that have historically benefited from State-sanctioned monopolies or a legacy of State investment.

Indian Government provides tax and non-tax investment incentives in specific sectors e.g. electronics and regions e.g. Northeast, Jammu \& Kashmir, Himachal Pradesh and Uttarakhand. It also provides incentives for manufacturing companies to set-up in Special Economic Zones (SEZ), Export Oriented Units (EOUs) and National Investment \& Manufacturing Zones (NIMZ). In addition, each state government has its own policy, providing additional investment incentives, including subsidised land prices, attractive interest rates on loans, reduced tariffs on electric power supply, tax concessions, etc. 
Also banks like, central government development banks and state industrial development banks offer medium to long-term loans for new projects. The Government has recently relaxed FDI policy in a variety of sectors by such measures as raising the foreign investment limit, easing conditions for investment and putting many sectors on the 'automatic route' as opposed to the 'Government route'. The sectors that benefited from the relaxation include real estate, private banking, defence, civil aviation, single brand retail and news broadcasting.

(b) Freedom of establishment: In China, though it varies according to the sector, but there is a requirement to submit a 'business plan' for approval prior to setting up of any business or industry in the country. In India, if the factory is located outside an industrial area, various approvals and clearances are required. An environmental site approval might also be required along with registration under State Sales Tax Act and Central and State Excise Acts and consent under Water and Air Pollution Control Acts.

(c) Obligation to declare: The China International Investment Promotion Agency facilitates the distribution of information on necessary authorisations for establishing a business in the country. All proposed foreign investment projects in China must be submitted for 'verification' and approval to the National Development and Reform Commission (NDRC) or to provincial or local Development and Reform Commissions (depending on the sector and value of the investment). In India, Mergers and acquisitions are generally governed by the Companies Act, 1956 and the sector-specific law. In case merger has cross-border aspects, the parties must comply with among others, the foreign direct investment policy of the Government - the Foreign Exchange Management. For listed companies, provisions of Listing Agreements with the stock exchange SEBI (Disclosure \& Investor Protection Guidelines)-2000, SEBI (Substantial Acquisition of Shares and Takeovers) Regulations- 1997 must be complied with.

(d) Acquisition of holdings: The acquisition of majority interest in a local company is authorised in China, according to the sectors. In India, acquisitions by private arrangement are considered contractual agreements between the parties and would take the form of share acquisitions, asset transfers, or slump sale.

(e) Specific authorisations in certain sectors: Business plans must be submitted for approval to competent authorities prior to the beginning of business activity. Greenfield investment projects must also seek approval from China's Environmental Protection Ministry and its Ministry of Land Resources. The Chinese Government maintains 'absolute control' over sectors including: aviation, coal, defence, electric power and the state grid, oil, petrochemicals, shipping and telecommunications. It also holds 'relative control' over the following sectors: automotive, chemical, construction, exploration and design, electronic information, equipment manufacturing, iron and steel, nonferrous 
metal, science and technology. In India, environment clearance from the Ministry of Environment and Forest is required for investment of foreign capital in fields like petrochemicals complexes, petroleum refineries, cement thermal power plants and bulk drugs.

(f) Office real estate and land ownership: In China, the renting a business centre by foreign companies is subject to restrictions in telecommunication, energy, environment, High technology and Service sectors. It is not possible to buy land in China, only a right of its use for 50 to 70 years can be approved. This is comparatively easier in India where it is easy to rent an office, showrooms, warehouses, and industrial premises. Foreign companies are allowed to buy land and building space for their business purpose.

(g) Investment aid: Both India and China encourages foreign investment through several measures and incentives, to attract investments into the country. These include tax holiday, tax concessions, and import of capital goods at concessional customs duty, Special Economic Zones (SEZs), bilateral investment protection agreements with investing countries; etc.

(i) Forms of Aid: In India, the incentives to attract investments into the country include tax holiday, tax concessions, and import of capital goods at concessional customs duty, Special Economic Zones (SEZs), bilateral investment protection agreements with investing countries; etc. Foreign investors in China enjoy corporate tax reductions, exemptions of tax on dividends repatriated during a certain period and other tax advantages. Moreover, foreign direct investment incentives include packages of reduced income taxes, resource and land use fees, and import/export duties, as well as priority treatment in obtaining basic infrastructure services, streamlined Government approvals, and funding support for start-ups.

(ii) Privileged domains: The privileged domains in India include power, ports, highways, electronics and software, scientific R\&D, manufacturing of energy-saving, environmental-protection and pollution-control equipment. China encourages foreign investment primarily in high technology, clean energy and export-oriented sectors.

(iii) Privileged geographical zones: Tax reductions are granted to companies who set up in Special Economic Zones (SEZ) in India. In China too, the Government has created various zones, granting each tax exemptions or tax incentives to attract overseas investments. They are primarily the 5 special economic zones and the 14 coastal cities.

\subsection{Differences in economic factors}

(a) Basic economic determinants: The basic economic factors that make India an attractive FDI destination are technical manpower, particularly in information technology and better English language skills, while in the case of China, it draws its 
strength from higher total and per capita GDP; higher literacy and education rates, large natural resource endowments, and competitive infrastructure. India has now developed specialization in IT services, call centres, business back-office operations and R\&D while China has become a key centre for hardware design and manufacturing.

(b) Overseas network: Overseas Indians are fewer, more of a professional group and often lack family network connections and financial resources to invest in India. Overseas Chinese are more in number, tend to be more entrepreneurial, enjoy family connections in China and have the interest and financial capability to invest in China

(c) Other factors: Outmoded labour laws (difficult entry and exit procedures which discourage the entry of greenfield FDI); bureaucratic controls and procedures and infrastructural bottlenecks have impeded FDI inflows into India. In comparison, China has easier FDI procedures, more flexible labour laws, a better labour climate and better entry and exit procedures for business.

\subsection{Conclusion}

Available data suggest that the share of India in FDI flows to developing countries is meagre. In spite of its strategic location, with access to a vast domestic and South Asian market, its share in world's total flow of direct investment to developing countries is very low. While the growth of FDI inflows to India has been fairly satisfactory, India's share in the global FDI regime in comparison to China is still minuscule. China attracts many times more FDI than India on a consistent basis. The above comparative analysis of the FDI policies and economic factors in the two countries reveals that India needs further liberalisation of norms for investment for present and prospective foreign entrepreneurs. To be competitive in attracting FDI, India needs to work more on developing an investor-friendly environment. The analysis underlines the need for efficient and adequate infrastructure, increased emphasis on education, development of business-friendly public administration and a greater connect with overseas Indians.

\section{References}

Akin, M. S. \& Vlad, V. (2011). The relationship between education and foreign direct investment: Testing the inverse U shape.European Journal of Economic and Political Studies, 4(1), 27-46.

Ali, S. and Guo, W. (2005). Determinants of FDI in China. Journal of Global Business and Technology, 1(2), 21-33. 
Cuervo-Cazurra, A. (2006). Who cares about corruption? Journal of International Business Studies, 37(6), 807-822.

Dumludag, D. (2009). An analysis of the determinants of foreign direct investment in Turkey: The role of the institutional context. Journal of Business Economics and Management, 10(1), 15-30.

Fedderke, J. W. \& Romm, A. T. (2006). Growth impact and determinants of foreign direct investment into South Africa, 1956-2003. Economic Modelling, 23(5), 738-760.

Fung, K. C., Garcia-Herrero, A., Iizaka, H. \& Siu, A. (2005). Hard or soft? Institutional reforms and infrastructure spending as determinants of foreign direct investment in China. Japanese Economic Review, 56(4), 408-416.

Godinez, J. R., \& Liu, L. (2015). Corruption distance and FDI flows into Latin America. International Business Review, 24(1), 33-42.

Goswami, G. G. and Haider, S. (2014). Does political risk deter FDI inflow? An analytical approach using panel data and factor analysis. Journal of Economic Studies, 41(2), 233-252.

Habib, M. and Zurawicki, L. (2002). Corruption and foreign direct investment. Journal of International Business Studies, 33(2), 291-307.

Julio, B., \& Yook, Y. (2016). Policy uncertainty, irreversibility, and cross-border flows of capital. Journal of International Economics, 103, 13-26.

Kahai, S. K. (2011). Traditional and non-traditional determinants of foreign direct investment in developing countries. Journal of Applied Business Research, 20(1), 43-50.

Mina, W. (2007). The location determinants of FDI in the GCC countries. Journal of Multinational Financial Management, 17(4), 336-348.

Murthy, K. V. \& Bhasin, N. (2015). The impact of bilateral tax treaties: A multi-country analysis of FDI inflows in India. The Journal of International Trade and Economic Development, 24(6), 751-766. 
126 | MUDRA: Journal of Finance and Accounting, Volume 4, Issue 2, Jul-Dec 2017

Noorbakhsh, F., Paloni, A. \& Youssef, A. (2001). Human capital and FDI inflows to developing countries: New empirical evidence. World Development, 29(9), 1593-1610.

Sury, N. (2008). Determinants of foreign direct investment in India. Foreign Trade Review, 42(4), 24-41.

Wernick, D. A., Haar, J. and Singh, S. (2009). Do governing institutions affect foreign direct investment inflows? New evidence from emerging economies. International Journal of Economics and Business Research, 1(3), 317-332. 